\title{
Report on Transport and Loading of Explosives in the Femtosecond Tank, Room 1711A HEAF 00-010
}

\author{
D. Hill
}

April 25, 2002

U.S. Department of Energy

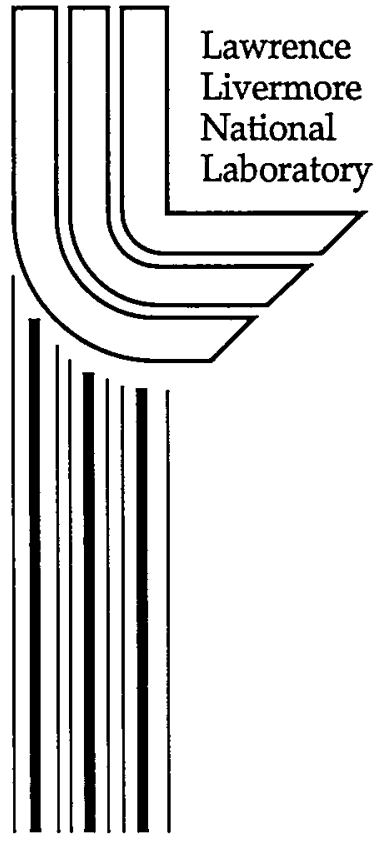




\section{DISCLAIMER}

This document was prepared as an account of work sponsored by an agency of the United States Government. Neither the United States Government nor the University of California nor any of their employees, makes any warranty, express or implied, or assumes any legal liability or responsibility for the accuracy, completeness, or usefulness of any information, apparatus, product, or process disclosed, or represents that its use would not infringe privately owned rights. Reference herein to any specific commercial product, process, or service by trade name, trademark, manufacturer, or otherwise, does not necessarily constitute or imply its endorsement, recommendation, or favoring by the United States Government or the University of California. The views and opinions of authors expressed herein do not necessarily state or reflect those of the United States Government or the University of California, and shall not be used for advertising or product endorsement purposes.

This work was performed under the auspices of the U. S. Department of Energy by the University of California, Lawrence Livermore National Laboratory under Contract No. W-7405-Eng-48.

This report has been reproduced directly from the best available copy.

Available electronically at http://www.doc.gov/bridge

Available for a processing fee to U.S. Department of Energy

And its contractors in paper from

U.S. Department of Energy

Office of Scientific and Technical Information

P.O. Box 62

Oak Ridge, TN 37831-0062

Telephone: (865) 576-8401

Facsimile: (865) 576-5728

E-mail: reports@adonis.osti.gov

Available for the sale to the public from

U.S. Department of Commerce

National Technical Information Service

5285 Port Royal Road

Springfield, VA 22161

Telephone: (800) 553-6847

Facsimile: (703) 605-6900

E-mail: orders@ntis.fedworld.gov

Online ordering: http://www.ntis.gov/ordering.htm

OR

Lawrence Livermore National Laboratory

Technical Information Department's Digital Library

http://www.llnl.gov/tid/Library.html 


\section{Report on Transport and Loading of Explosives In the Femtosecond Tank, Room 1711A HEAF 00-010}

Prepared By:

David L. Hill

Explosives Safety Engineer

Concurred By:

Jim Dotts

Explosives Safety Engineer

Concurred By:

Jerry Benterou

EE Technical Associate

Concurred By:

Larry Crouch

HEAF Firing Operations Supervisor

Approved by:

William Gilliam

HEAF Facility Manager

Distribution Date:

Uncontrolled Distribution:

$\begin{array}{llll}\text { Benterou, Jerry } & \text { L-281 } & \text { Roeske, Frank } & \text { L-281 } \\ \text { Crouch, Larry } & \text { L-283 } & \text { Wilson, Ross } & \text { L-345 } \\ \text { Dotts, Jim } & \text { L-281 } & \text { Yee, Danny } & \text { L-293 } \\ \text { Gilliam, William } & \text { L-281 } & \text { File } & \\ \text { Ingram, Carl } & \text { L-170 } & & \\ \text { Lee, Roanne } & \text { L-284 } & & \\ \text { Lee, Ronald S. } & \text { L-281 } & & \\ \text { Maienschein, Jon } & \text { L-282 } & & \\ \text { Schwieckert, Jerry } & \text { L-143 } & & \end{array}$




\begin{abstract}
The current OSP associated with Room 1711A located in Building 191 (HEAF) sets a limit of 5 grams Net Explosive Weight (NEW) of explosives for the room. A question was raised as to the capability of that room to withstand the overpressure created by a detonation of 5 grams NEW of explosives. Calculations were inconclusive, but indicated the wallboard would not remain intact if there was a detonation of 5 grams NEW at a distance of eight feet from the wall. These calculations did not seem logical.
\end{abstract}

To verify the hypothesis, a series of experiments were conducted in the 1 Kilogram tank. The experiments consisted of exposing a pre-built double-sided wall with the same stud spacing and drywall thickness found in the walls of Room 1711A to various amounts of explosives to create expected overpressures. The objective of this test was to prove or disprove that the walls in room 1711A could withstand a detonation of 5 grams of high explosives and to determine if larger quantities of explosives could be worked on in the room while still providing the required level of protection for personnel outside the room.

Testing has verified that not only can the walls withstand a 5 gram explosion, but a 10.75 gram explosion as well. A second test was conducted using 20 grams of explosive plus a detonator. Although the inner piece of drywall cracked, the outer piece of drywall maintained its integrity, thereby confining the effects of the anticipated overpressure to the room.

\title{
Test set up:
}

a. The test wall was constructed to similar standards as the subject wall. (See Photo 1)

b. Test number one consisted of a 10 gram sample of C-4 along with a $1 \mathrm{E}-26$ detonator (NEW 10.75 grams). The charge was assembled and placed a distance of 6 feet from the wall at a height of 3 feet. (See Photos $2 \& 3$ )

c. Test number two consisted of a 10 gram sample of C-4 along with a 1E-26 detonator (NEW 10.75 grams). The charge was assembled and placed a distance of 3 feet from the wall at a height of 3 feet.

d. Test number three consisted of 20 grams of C-4 plus a detonator (NEW 20.75 grams). The charge was assembled and placed 6 feet from the wall at a height of 6 inches. (See Photo 5)

e. Test number four involved an RP-1 detonator place 6 feet from the wall at a height of 3 feet and oriented as to project the fragment pattern towards the wall (no photo). 


\section{Data Collection:}

a. Still photos were obtained before and after each test

\section{Results:}

1. When exposed to a 10.75 gram NEW detonation as specified in the test configuration at both $3 \& 6$ feet, no damage was noted to the wall. (See photo 4)

2. When exposed to a 20.75 gram NEW detonation as specified in the test configuration at 6 feet, only the inner wall showed signs of cracking, while the outer wall sustained no damage. (See photos 6, $7 \& 8$ )

3. When exposed to the RP-1 detonator as specified in the test configuration, no fragment damage to the wall was noted.

\section{Conclusions:}

1. A Maximum Credible Event (MCE) of 10 grams NEW presents no significant hazard to the personnel outside the room as long as a minimum 3 feet standoff distance is maintained. It is felt that the $125 \%$ rule for determining the 10 gram MCE has been met with the minimal damage that occurred with the 20.75 gram test.

2. Testing verified that the room is not only capable of containing a 5 gram detonation, but a detonation of 10.75 grams with a standoff distance of at least three feet and up to 20.75 grams (with a standoff distance of 6 feet) as well.

\section{Recommendations:}

1. Allow work to proceed as currently described in the HEAF FSP and Femtosecond OSP 191.87

2. Update the HEAF SAR, FSP and OSP 191.87 to reflect the results of the physical tests allowing an increase in Room 1711A to an NEW of 10 grams.

David L. Hill

Explosives Safety Engineer 


\section{Diagram of the tests layout.}

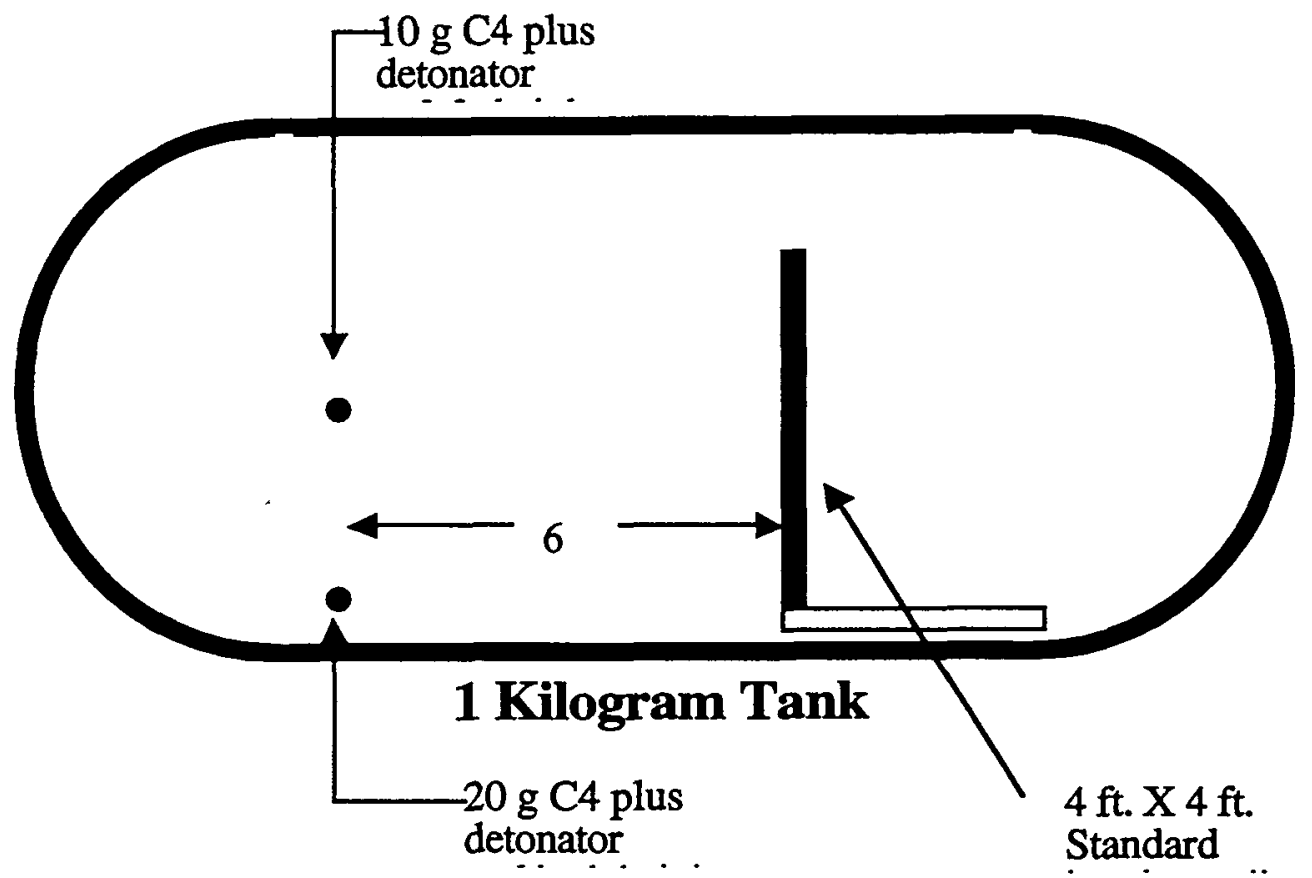




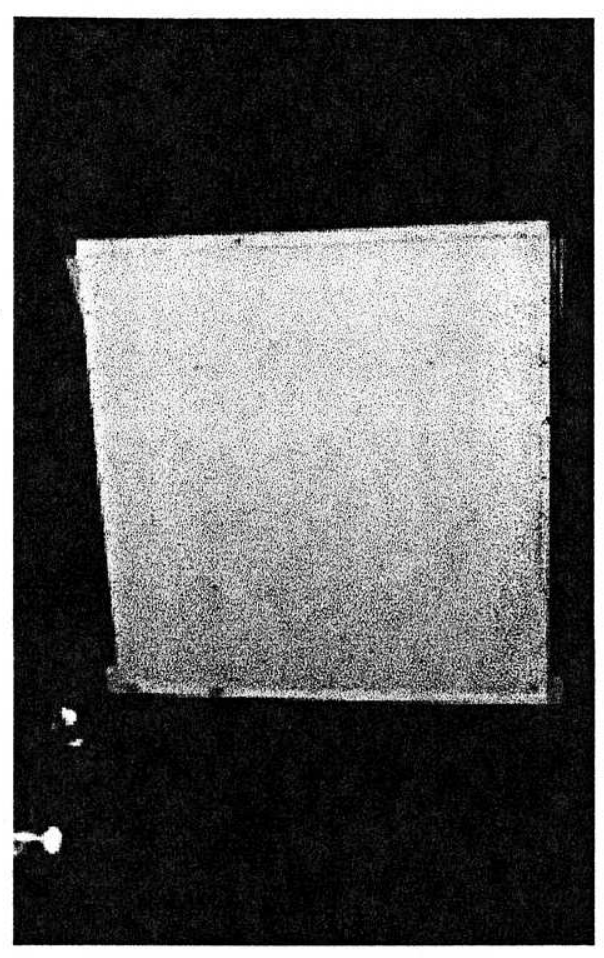

PHOTO 1 - New Wall

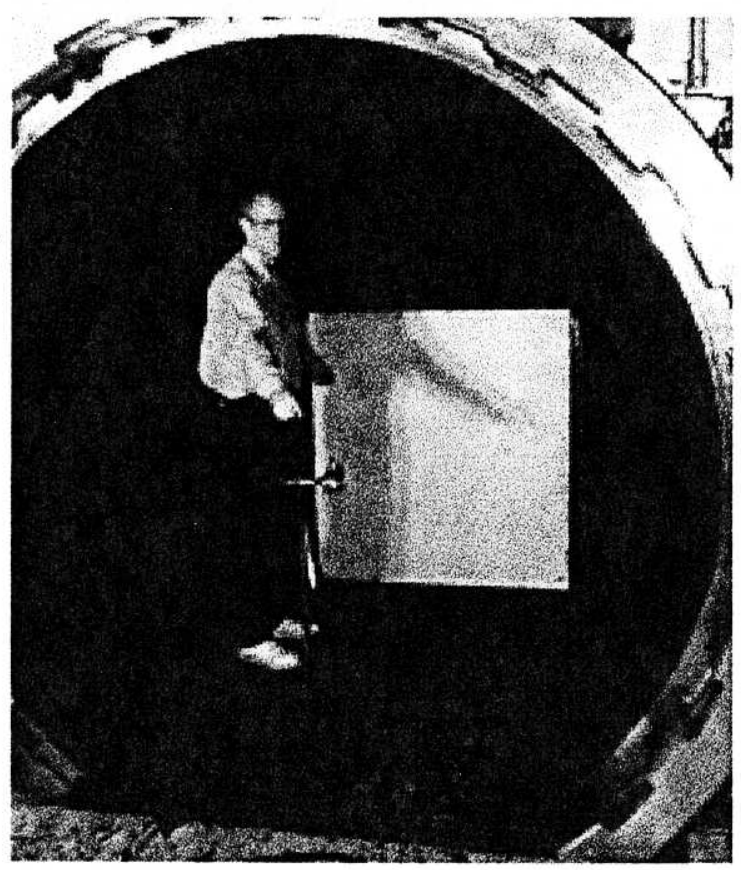

PHOTO 3 - 10.75 grams NEW at 6 feet from wall at a height of 3 feet.

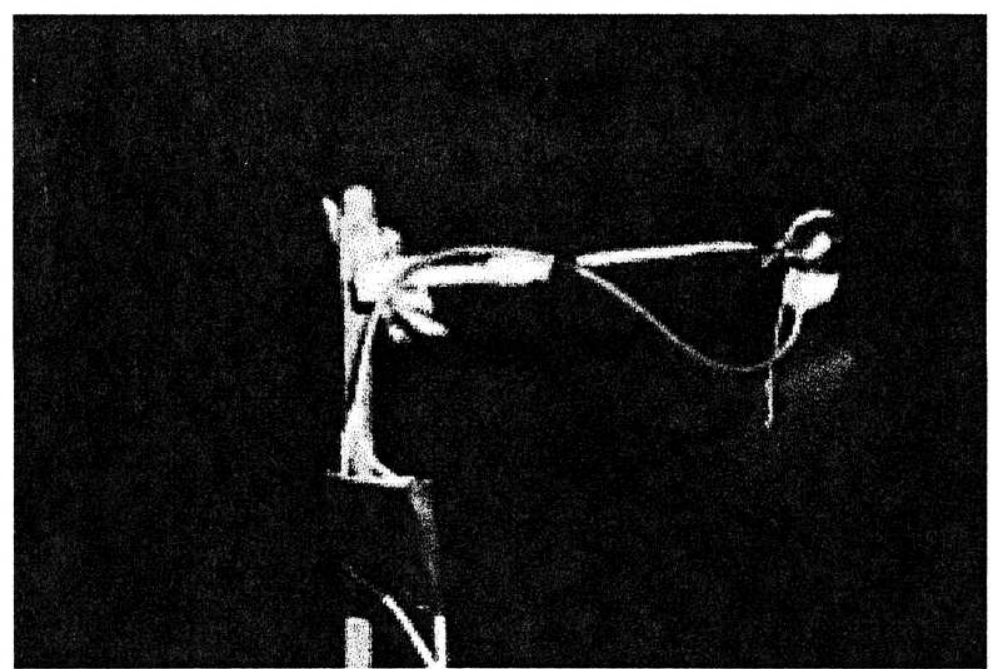

PHOTO 2 - 10 grams $\mathrm{C} 4$ plus detonator

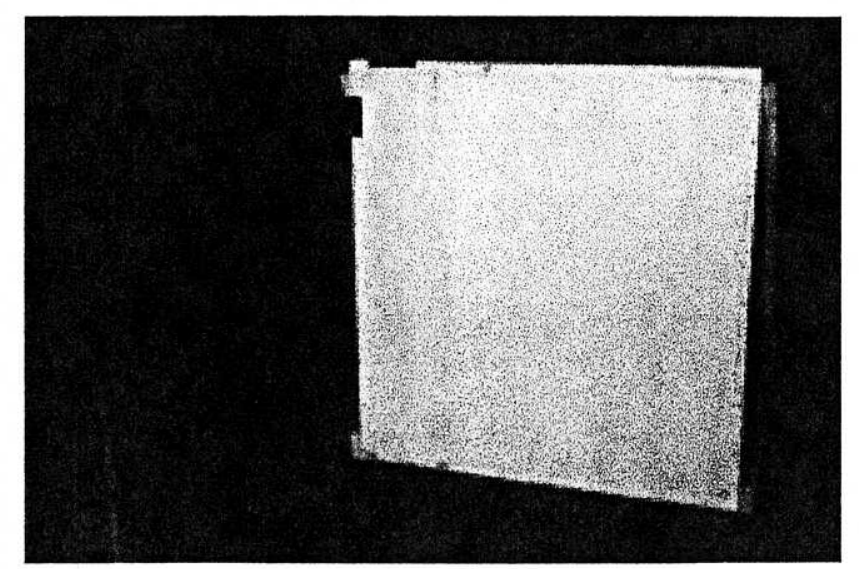

PHOTO 4 - Undamaged wall after 10.75 grams detonation.

Report on Transport and Loading of Explosives In the Femtosecond Tank, Room 1711A

HEAF 00-010, Revision 0, 12/18/00 


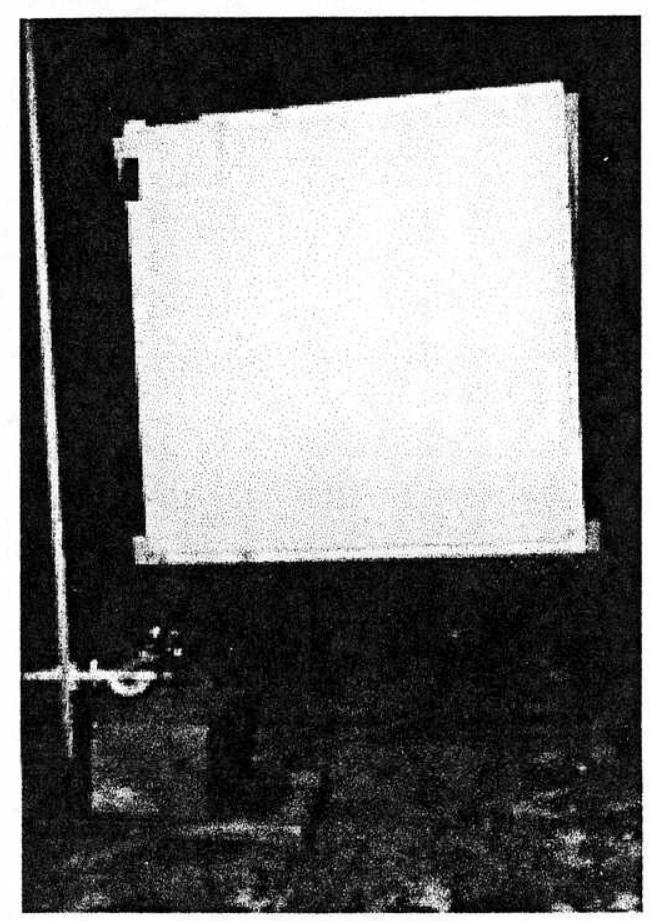

PHOTO 5 - 20 grams $\mathrm{C} 4$ plus detonator at a distance of 6 feet and height of 6 inches

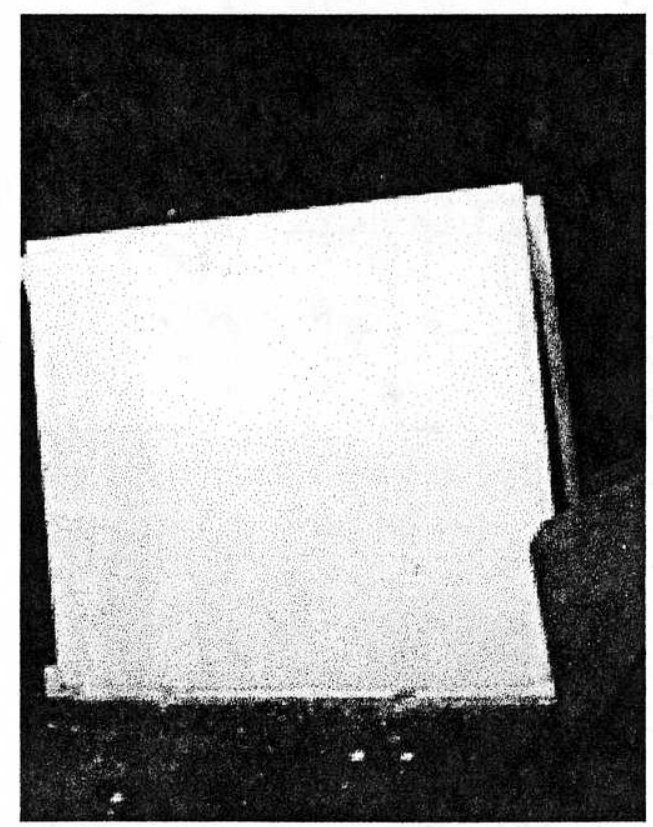

PHOTO 7 - Another view of cracked wall

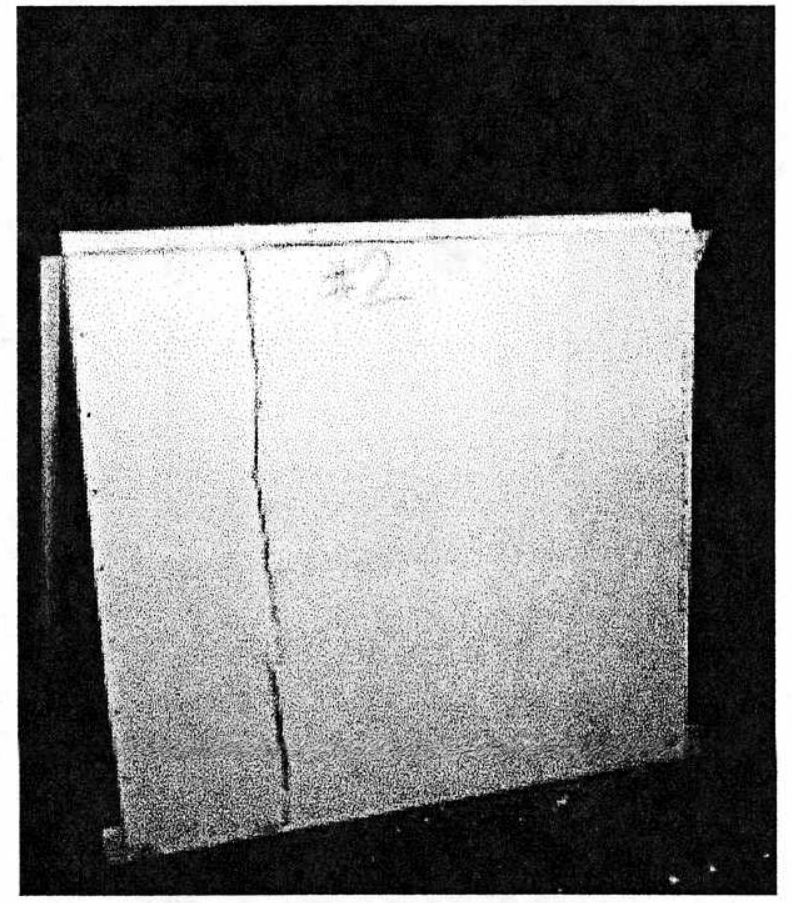

PHOTO 6 - View of cracked wall after the 20.75 grams NEW detonation.

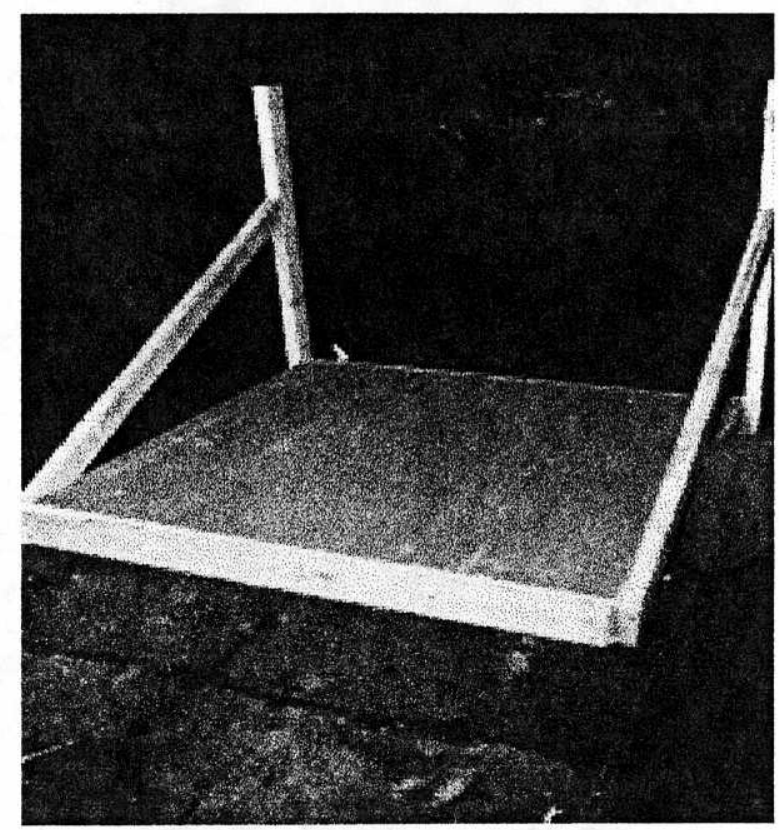

PHOTO 8 - Undamaged outer wall after 20.75 grams detonation. 